\title{
Organic Acids Production by Zinc Solubilizing Bacterial Isolates
}

\author{
D.N. Vidyashree ${ }^{1}$, R. Muthuraju ${ }^{1 *}$, P. Panneerselvam ${ }^{2}$ and Debasis Mitra ${ }^{2}$ \\ ${ }^{1}$ University of Agricultural Sciences, GKVK, Bengaluru, Karnataka 560 065, India \\ ${ }^{2}$ Crop Production Division, ICAR - National Rice Research Institute, Cuttack, \\ Odisha 753 006, India \\ *Corresponding author
}

\begin{abstract}
A B S T R A C T
Zinc $(\mathrm{Zn})$ is the most effective micronutrient and $\mathrm{Zn}$ solubilization is triggered by the production of organic acids for the optimum growth of plants. An investigation was carried

Keywords

$\mathrm{ZSB}, B$.

aryabhattai,

Organic acids,

HPLC

Article Info

Accepted:

06 September 2018

Available Online:

10 October 2018 out on organic acid production profiling during zinc solubilization by zinc solubilizing bacterial (ZSB) strains (B. aryabhattai, Pseudomonas taiwenensis and Bacillus sp. PANTM1) which were obtained from the Culture Collection Centre, Microbiology Laboratory, SSAC, ICAR-IIHR, Bengaluru, India. Eleven organic acids profile was estimated by HPLC in different zinc sources viz., zinc oxide $(\mathrm{ZnO})$, zinc carbonate $\left(\mathrm{ZnCO}_{3}\right)$ and zinc phosphate $\left[\mathrm{Zn}_{3}\left(\mathrm{PO}_{4}\right)_{2}\right]$ by the three $\mathrm{ZSB}$ isolates which revealed that lactic acid (9128 $\mu \mathrm{g} \cdot \mathrm{ml}^{-1}$, in $\mathrm{ZnCO}_{3}-15$ days), malonic acid [9456 $\mu \mathrm{g} \cdot \mathrm{ml}^{-1}$, in $\mathrm{Zn}_{3}\left(\mathrm{PO}_{4}\right)_{2}-10$ days], malic acid $\left(6949 \mu \mathrm{g} \cdot \mathrm{ml}^{-1}\right.$, in $\mathrm{Zn}_{3}\left(\mathrm{PO}_{4}\right)_{2}$-10days), citric acid [8887 $\mu \mathrm{g} \cdot \mathrm{ml}^{-1}$, in $\mathrm{Zn}_{3}\left(\mathrm{PO}_{4}\right)_{2}-5$ days] and succinic acid $\left[9005 \mu \mathrm{g} . \mathrm{ml}^{-1}\right.$, in $\mathrm{ZnCO}_{3}-10$ days] are the major organic acids produced by the isolates used in the study. Among the ZSB strain, B. aryabhattai produced all most all the organic acids during zinc solubilization as compared to P. taiwenensis and Bacillus sp. PAN-TM1. The above findings clearly indicated that the organic acids secretions by Bacillus and Pseudomonas will vary depend on the substrate of $\mathrm{Zn}$ minerals.
\end{abstract}

\section{Introduction}

Zinc $(\mathrm{Zn})$ is an essential micronutrient required for plants, animals, and humans for their normal growth and reproduction (Frassinetti et al., 2006).

In plants, zinc plays a key role as a structural constituent or regulatory co-factor of a wide range of different enzymes and proteins in many important biochemical pathways (Ghosh et al., 2014). Total and available $\mathrm{Zn}$ content in Indian soils ranged between 7-2960 $\mathrm{mg} \mathrm{kg}^{-1}$ and $0.1-24.6 \mathrm{mg} \mathrm{kg}^{-1}$ respectively with an average deficiency of 12 to $87 \%$. According to the FAO, about $30 \%$ of the cultivable soils of the world contain low levels of plant available Zn (Sillanpaa, 1990).

Many Indian soils exhibit the deficiency of Zn with the content much below the critical level of 1.5ppm (Tiwari and Dwivedi, 1994). Thus $\mathrm{Zn}$ deficiency has become a serious problem affecting nearly half of the world's population (Cakmak, 2009). To overcome this constraint external addition of soluble $\mathrm{Zn}$ to alleviate deficiency results in the transformation of about $96-99 \%$ to various fractions of 
unavailable forms and about 1-49\% is left as available fraction in the soil. Therefore, efficient and economical methods to correct $\mathrm{Zn}$ deficiency have to be devised. Recently a bacterial based approach was devised to solve these micronutrient deficiency problems (Anthoni, 2002).

The rhizosphere microorganisms play a pivotal role in the enhancement of crop production by the solubilization of unavailable form of metal into available form. This mineral solubilization was due to the production of organic acids and $\mathrm{pH}$ drop by organisms (Alexander, 1997).

Plants take up $\mathrm{Zn}$ as $\left(\mathrm{Zn}^{2+}\right)$ divalent cation. The organic acids released sequester the cations and acidify the micro environment near root is thought to be a major mechanism of $\mathrm{Zn}$ solubilization.

In addition, the anions can chelate $\mathrm{Zn}$ and increase $\mathrm{Zn}$ solubility, which results in the enhanced available form of $\mathrm{Zn}^{2+}$ to plants (Jones and Darrah, 1994). Hence, it is plausible that the exploitation of native zinc mineralizing and solubilizing bacteria may aid in overcoming zinc deficiency and increased the availability of zinc to crops. In the present study, the ability of different rhizobacteria to solubilize inorganic $\mathrm{Zn}$ compounds in-vitro was tested and also identified the organic acids aiding in zinc solubilization.

\section{Materials and Methods}

\section{Bacterial strains}

The three zinc solubilizing bacterial strains ( $B$. aryabhattai, $P$. taiwenensis and Bacillus sp. (PAN-TM1) included in the present study were procured from the Culture Collection Centre, Microbiology Laboratory, Division of Soil Science and Agricultural Chemistry, ICAR-IIHR, Hesaraghatta, Bengaluru, India.
Organic acids analysis by High Performance Liquid Chromatography (HPLC)

HPLC reverse-phase chromatography was used for the analysis of organic acids produced by bacterial isolates in broth culture. One $\mathrm{ml}$ of bacterial cultures were inoculated to the sterilized liquid basal medium containing $0.1 \%$ different zinc sources such as $\mathrm{ZnO}, \mathrm{ZnCO}_{3}$ and $\mathrm{Zn}_{3}\left(\mathrm{PO}_{4}\right)_{2}$. The samples were withdrawn at 5, 10 and 15 days intervals, centrifuged to remove the debris and cells. The supernatant was collected and filtered through $0.2 \mu \mathrm{m}$ poly vinylidenedifluoride (PVDF) syringe filters and estimated the different organic acids by HPLC (Model: Prominence, Shimadzu, Japan) technique (Tahir and Shakeel, 2013). The organic acids detected were identified by comparing their retention time and the peak areas of their chromatograms with the standard organic acids.

\section{Results and Discussion}

HPLC analysis of the culture filtrates was done to identify and quantify the organic acids produced during solubilization of insoluble zinc sources $\left(\mathrm{ZnO}, \quad \mathrm{Zn}_{3} \quad\left(\mathrm{PO}_{4}\right)_{2}\right.$ and $\mathrm{ZnCO}_{3}$ ).Totally eleven different organic acids were estimated. Among the eleven organic acids estimated, B. aryabhattai has produced (Table 1) a maximum amount of malic acid $\left(6244 \mu \mathrm{g} \cdot \mathrm{ml}^{-1}\right)$, malonic acid $\left(3757 \mu \mathrm{g} \cdot \mathrm{ml}^{-1}\right)$, succinic acid $\left(662 \mu \mathrm{g} \cdot \mathrm{ml}^{-1}\right)$, citric acid $\left(413 \mu \mathrm{g} \cdot \mathrm{ml}^{-1}\right)$, propionic acid $\left(240 \mu \mathrm{g} \cdot \mathrm{ml}^{-1}\right)$, keto-D-gluterate $\left(166 \mu \mathrm{g} \cdot \mathrm{ml}^{-1}\right)$ and gluconic acid $\left(6.56 \mu \mathrm{g} . \mathrm{ml}^{-1}\right)$ in broth supplemented with zinc oxide. More production of malic was recorded after 5 days of incubation; remaining organic acids production was high at 15 days after incubation. When zinc carbonate was used, the maximum production of lactic acid $\left(9128 \mu \mathrm{g} \cdot \mathrm{ml}^{-1}\right)$, succinic acid $\left(9005 \mu \mathrm{g} \cdot \mathrm{ml}^{-1}\right)$, malic acid $\left(2982 \mu \mathrm{g} \cdot \mathrm{ml}^{-1}\right)$, malonic acid 
$\left(2070 \mu \mathrm{g} \cdot \mathrm{ml}^{-1}\right)$, propionic acid $\left(234 \mu \mathrm{g} \cdot \mathrm{ml}^{-1}\right)$, keto-D-gluterate $\left(192 \mu \mathrm{g} \cdot \mathrm{ml}^{-1}\right)$, formic acid $\left(34 \mu \mathrm{g} \cdot \mathrm{ml}^{-1}\right)$, gluconic acid $\left(2.99 \mu \mathrm{g} \cdot \mathrm{ml}^{-1}\right)$ and oxalic acid $\left(0.18 \mu \mathrm{g} \cdot \mathrm{ml}^{-1}\right)$ was recorded. But, the maximum production of lactic acid was found 10 days after incubation compared to all other organic acids. When zinc phosphate was used, the highest production of malonic acid $\left(9456 \mu \mathrm{g} \cdot \mathrm{ml}^{-1}\right)$, malic acid $\left(6949 \mu \mathrm{g} \cdot \mathrm{ml}^{-1}\right)$, tartaric acid $\left(1261 \mu \mathrm{g} . \mathrm{ml}^{-1}\right)$, keto-D-gluterrate $\left(335 \mu \mathrm{g} \cdot \mathrm{ml}^{-1}\right)$, propionic acid $\left(258 \mu \mathrm{g} \cdot \mathrm{ml}^{-1}\right)$ and formic acid $\left(133 \mu \mathrm{g} \cdot \mathrm{ml}^{-1}\right)$ was observed after 10 days of inoculation. Whereas the highest production of lactic acid $\left(4111 \mu \mathrm{g} \cdot \mathrm{ml}^{-1}\right)$, citric acid $\left(8887 \mu \mathrm{g} \cdot \mathrm{ml}^{-1}\right)$ and succinic acid $\left(1237 \mu \mathrm{g} \cdot \mathrm{ml}^{-1}\right)$ were observed after 5 days of incubation. Out of eleven organic acids estimated B. aryabhattai could produce all most all the organic acids except tartaric acid and lactic acid in medium supplemented with zinc oxide.

P. taiwenensis could produce (Table 2) malonic acid $\left(1077 \mu \mathrm{g} \cdot \mathrm{ml}^{-1}\right)$, keto-D-gluterate $\left(212 \mu \mathrm{g} \cdot \mathrm{ml}^{-1}\right)$, citric acid $\left(61 \mu \mathrm{g} \cdot \mathrm{ml}^{-1}\right)$, propionic acid $\left(235 \mu \mathrm{g} \cdot \mathrm{ml}^{-1}\right)$, gluconic acid $\left(3.45 \mu \mathrm{g} \cdot \mathrm{ml}^{-1}\right)$ and oxalic acid $\left(0.62 \mu \mathrm{g} \cdot \mathrm{ml}^{-1}\right)$ while zinc oxide as a source.

Whereas in the case of zinc carbonate is used, all the eleven organic acid productions were recorded. In this study, the maximum production of malic acid $\left(8830 \mu \mathrm{g} \cdot \mathrm{ml}^{-1}\right)$ followed by malonic acid $\left(4992 \mu \mathrm{g} \cdot \mathrm{ml}^{-1}\right)$ and succinic acid $\left(2829 \mu \mathrm{g} \cdot \mathrm{ml}^{-1}\right)$ was recorded after 10 days of incubation. All the eleven organic acids was recorded in medium supplemented with zinc phosphate, however the following organic acids viz., malic acid $\left(5649 \mu \mathrm{g} . \mathrm{ml}^{-}\right.$ $\left.{ }^{1}\right)$ followed by malonic acid $\left(3722 \mu \mathrm{g} \cdot \mathrm{ml}^{-1}\right)$, lactic acid $\left(3939 \mu \mathrm{g} \cdot \mathrm{ml}^{-1}\right)$, citric acid $\left(1023 \mu \mathrm{g} \cdot \mathrm{ml}^{-1}\right)$ and succinic acid $\left(1080 \mu \mathrm{g} \cdot \mathrm{ml}^{-1}\right)$ were found to be maximum. $P$. taiwenensis was unable toproduce malic acid, tartaric acid, lactic acid and succinic acid in medium supplemented with zinc oxide source.
The organic acids estimated in Bacillus sp. (PAN-TM1) (Table 3) inoculated to the medium supplemented with zinc oxide, the maximum production of lactic acid $\left(2609 \mu \mathrm{g} \cdot \mathrm{ml}^{-1}\right)$, followed by malic acid $\left(7580 \mu \mathrm{g} \cdot \mathrm{ml}^{-1}\right)$, malonic acid $\left(6062 \mu \mathrm{g} \cdot \mathrm{ml}^{-1}\right)$, succinic acid $\left(2119 \mu \mathrm{g} \cdot \mathrm{ml}^{-1}\right)$ and citric acid $\left(9909 \mu \mathrm{g} . \mathrm{ml}^{-1}\right)$ was observed after 10 days of incubation.

Wherein when zinc carbonate used, the malic acid $\left(9104 \mu \mathrm{g} \cdot \mathrm{ml}^{-1}\right)$ after 5 days followed by malonic acid $\left(7103 \mu \mathrm{g} \cdot \mathrm{ml}^{-1}\right)$, citric acid $\left(4225 \mu \mathrm{g} \cdot \mathrm{ml}^{-1}\right)$ and succinic acid $\left(1069 \mu \mathrm{g} \cdot \mathrm{ml}^{-1}\right)$ was found maximum after 10 days of incubation. In case of zinc phosphate as a source, the lactic acid $\left(2250 \mu \mathrm{g} \cdot \mathrm{ml}^{-1}\right)$ was recorded maximum after 15 days of incubation followed by malic acid $\left(7828 \mu \mathrm{g} \cdot \mathrm{ml}^{-1}\right)$, malonic acid $\left(7808 \mu \mathrm{g} \cdot \mathrm{ml}^{-1}\right)$, succinic acid $(1468 \mu \mathrm{g}$. $\left.\mathrm{ml}^{-1}\right)$ and citric acid $\left(1280 \mu \mathrm{g} \cdot \mathrm{ml}^{-1}\right)$.

There was a restricted production of keto-Dglutaric acid, lactic acid and oxalic acid by Bacillus sp. (PAN-TM1) when zinc carbonate and zinc phosphate was incorporated into the medium.

In the terrestrial environment, mobilization of insoluble metal compounds is important for the release of essential minerals $(\mathrm{Mn}, \mathrm{Fe}$ and $\mathrm{Zn})$ as well as associated anionic nutrients, e.g. phosphate, into biogeochemical cycles (Gadd, 1999). This depends mainly on the excretion of various metabolites, including organic acids and protons (Sayer et al., 1995).

The organic acid production (especially gluconic acid) is the primary mode of action for $\mathrm{Zn}$ dissolution, these low-molecularweight acids can non-specifically solubilize zinc, phosphorus, potassium, calcium, and manganese from their respective minerals or from insoluble precipitates depending upon the physico-chemical properties of the soil (Uroz et al., 2009). 
Table.1 Organic acids production of $B$. aryabhattai in nutrient broth supplemented with $0.1 \%$ different Zn sources at different intervals

\begin{tabular}{|c|c|c|c|c|c|c|c|c|c|}
\hline \multirow[t]{3}{*}{ Organic Acids } & \multicolumn{9}{|c|}{ Organic acid production $\left(\mu \mathrm{g} \mathrm{ml}^{-1}\right)$} \\
\hline & \multicolumn{3}{|c|}{$\mathrm{ZnO}$} & \multicolumn{3}{|c|}{$\mathrm{ZnCO}_{3}$} & \multicolumn{3}{|c|}{$\mathrm{Zn}_{3}\left(\mathbf{P O}_{4}\right)_{2}$} \\
\hline & 5days & 10days & 15days & 5days & 10days & 15days & 5days & 10days & 15days \\
\hline Keto-D-Gluterate & 160 & 166 & 104 & 192 & 138 & 120 & 233 & 335 & 304 \\
\hline Tartaric acid & 0.00 & 0.00 & 0.00 & 25 & 0 & 0 & 1138 & 1261 & 974 \\
\hline Formic acid & 32 & 28 & 34 & 0 & 34 & 21 & 104 & 133 & 55 \\
\hline Malic acid & 6244 & 3605 & 680 & 0 & 0 & 2982 & 5651 & 6949 & 3256 \\
\hline Malonic acid & 3757 & 2686 & 3547 & 687 & 2070 & 1631 & 6968 & 9456 & 2422 \\
\hline Lactic acid & 0 & 0.00 & 0.00 & 0 & 1244 & 9128 & 4111 & 0 & 0 \\
\hline Citric acid & 142 & 47 & 413 & 39 & 550 & 741 & 8887 & 4742 & 175 \\
\hline Succinic acid & 0.00 & 0.00 & 662 & 0 & 9005 & 7066 & 1237 & 1222 & 0 \\
\hline Propionic acid & 234 & 234 & 240 & 234 & 0 & 234 & 253 & 258 & 234 \\
\hline Gluconic acid & 0.69 & 6.56 & 4.23 & 2.99 & 0.51 & 1.91 & 1.71 & 19.52 & 34.69 \\
\hline Oxalic acid & 0.00 & 0.45 & 0.08 & 0.18 & 0.00 & 0.11 & 0.05 & 0.47 & 0.634 \\
\hline
\end{tabular}


Table. 2 Organic acids production of $P$. taiwenensis in nutrient broth supplemented with $0.1 \%$ different Zinc sources at different intervals

\begin{tabular}{|c|c|c|c|c|c|c|c|c|c|}
\hline \multirow[t]{3}{*}{ Organic acids } & \multicolumn{9}{|c|}{ Organic acid production $\left(\mu \mathrm{g} \cdot \mathrm{ml}^{-1}\right)$} \\
\hline & \multicolumn{3}{|c|}{$\mathrm{ZnO}$} & \multicolumn{3}{|c|}{$\mathrm{ZnCO}_{3}$} & \multicolumn{3}{|c|}{$\mathrm{Zn}_{3}\left(\mathbf{P O}_{4}\right)_{2}$} \\
\hline & 5days & 10days & 15days & 5days & 10days & 15days & 5days & 10days & 15days \\
\hline Keto-D-Gluterate & 0 & 101 & 212 & 244 & 354 & 91 & 111 & 204 & 867 \\
\hline Tartaric acid & 0 & 0 & 0 & 1078 & 1864 & 0 & 0 & 1349 & 28 \\
\hline Formic acid & 610 & 6 & 0 & 20 & 126 & 4 & 46 & 173 & 0 \\
\hline Malic acid & 0 & 0 & 0 & 4497 & 8830 & 2093 & 0 & 5649 & 0 \\
\hline Malonic acid & 0 & 1077 & 7.97 & 4951 & 4992 & 1258 & 6713 & 3722 & 439 \\
\hline Lactic acid & 0 & 0 & 0 & 8294 & 1283 & 1832 & 1498 & 3939 & 392 \\
\hline Citric acid & 0 & 50 & 61 & 3444 & 3146 & 99 & 724 & 1023 & 133 \\
\hline Succinic acid & 0 & 0 & 0 & 2178 & 2829 & 546 & 1469 & 1080 & 0 \\
\hline Propionic acid & 235 & 234 & 234 & 259 & 303 & 234 & 249 & 256 & 237 \\
\hline Gluconic acid & 0.64 & 0.65 & 3.45 & 33.3 & 29.11 & 18.61 & 6.7 & 14.14 & 31.05 \\
\hline Oxalic acid & 0.62 & 0.06 & 0.32 & 0.89 & 0.63 & 1.05 & 0.23 & 0.30 & 0.12 \\
\hline
\end{tabular}


Table.3 Organic acids production of Bacillus sp. (PAN-TM1) in nutrient broth supplemented with $0.1 \%$ different zinc sources at different intervals

\begin{tabular}{|c|c|c|c|c|c|c|c|c|c|}
\hline \multirow[t]{3}{*}{ Organic acids } & \multicolumn{9}{|c|}{ Organic acid production $\left(\mu \mathrm{g} \cdot \mathrm{ml}^{-1}\right)$} \\
\hline & \multicolumn{3}{|c|}{$\mathrm{ZnO}$} & \multicolumn{3}{|c|}{$\mathrm{ZnCO}_{3}$} & \multicolumn{3}{|c|}{$\mathrm{Zn}_{3}\left(\mathrm{PO}_{4}\right)_{2}$} \\
\hline & 5days & 10days & 15days & 5days & 10days & 15days & 5days & 10days & 15days \\
\hline Keto-D-Gluterate & 0 & 0 & 0 & 408 & 264 & 237 & 432 & 453 & 444 \\
\hline Tartaric acid & 2055 & 0 & 0 & 3025 & 1605 & 0 & 0 & 1751 & 1869 \\
\hline Formic acid & 304 & 341 & 245 & 259 & 283 & 528 & 65 & 150 & 17 \\
\hline Malic acid & 3495 & 7580 & 5419 & 9104 & 5324 & 5636 & 4606 & 3124 & 7828 \\
\hline Malonic acid & 5905 & 6062 & 5537 & 2737 & 7103 & 5662 & 1241 & 7808 & 0 \\
\hline Lactic acid & 1853 & 2609 & 2333 & 0 & 0 & 0 & 1513 & 0 & 2250 \\
\hline Citric acid & 5442 & 9909 & 7841 & 3993 & 4225 & 2996 & 3888 & 2061 & 1280 \\
\hline Succinic acid & 1460 & 2119 & 2028 & 1429 & 1069 & 1047 & 1468 & 1540 & 1168 \\
\hline Propionic acid & 238 & 269 & 243 & 269 & 260 & 251 & 252 & 275 & 291 \\
\hline Gluconic acid & 6.42 & 1.81 & 1.78 & 13.43 & 1.52 & 4.94 & 2.03 & 4.21 & 5.08 \\
\hline Oxalic acid & 0.82 & 0.09 & 0.18 & 0.204 & 0.06 & 0.08 & 0 & 0 & 0 \\
\hline
\end{tabular}


The organic acids can adhere to the mineral surface and extract the nutrients nonspecifically from the mineral particles through electron transfer; break the oxygen links in the minerals and release the nutrients and chelate ions present in the solution through carboxyl and hydroxyl groups and thereby indirectly accelerating the dissolution rate of minerals (Welch et al., 2002). Organic acids provide both sources of protons for mobilization and metal chelating anion to complex the metal cations (Devevre et al., 1996). In the present study profiles of organic acids produced in different zinc sources by the bacteria revealed that lactic acid, malonic acid, malic acid and succinic acid was the major and maximum produced organic acids by the isolates. The other organic acid produced includes keto-D-gluterate, citric acid, propionic acid, oxalic acid, tartaric acid and gluconic acid. The production of organic acids by zinc solubilizing bacteria has been reported, where $P$. fluorescens produced gluconic acid and 2-keto-gluconic acids in the culture broth during zinc phosphate solubilization (DiSimine et al., 1998).

The release of organic acids that sequester cations and acidify the micro environment is thought to be a major mechanism of $\mathrm{Zn}$ solubilization. A number of organic acids such as citric, acetic, propionic, lactic, oxalic, glycolic, gluconic acid etc., have been considered due to its effect in $\mathrm{pH}$ lowering by microorganisms (Cunningham et al., 1992).

From the present study, it is concluded that the production of eleven different organic acids by these zinc solubilizing bacterial strains play an important role in the solubilization of unavailable forms of zinc. Organic acids also responsible for lowering the $\mathrm{pH}$ of the medium or rhizosphere. Overall, these mechanisms convert unavailable form of zinc to available form as it is essential for the plant for its growth and development.

\section{Acknowledgements}

The authors gratefully thank the Director, ICAR - Indian Institute of Horticultural Research, Bengaluru for the support and infrastructure facilities.

\section{References}

Alexander, M. 1997. Introduction to soil microbiology. John Wiley and sons, New York. Asia, P.E.A. pp. 33 - 399.

Anthoni, R. 2002. Biofertilizers for micronutrients. Biofert. Newsletter. 10: 8-10.

Cakmak, I. 2009. Enrichment of fertilizers with zinc: an excellent investment for humanity and crop production in India. Journal of Trace Elements in Medicine and Biology. 23(4): 281-289

Cunningham, J.E., Kuiack, C. 1992. Production of citric and oxalic acids and solubilization of calcium phosphate by Penicillium bilaii. Applied and Environmental Microbiology. 58(5): 1451-1458.

Devevre, O., Garbaye, J., Botton, B. 1996. Release of complexing organic acids by rhizosphere fungi as a factor in Norway spruce yellowing in acidic soils. Mycological Research. 100(11): 13671374.

Di Simine, C.D., Sayer, J.A., Gadd, G. M. 1998. Solubilization of zinc phosphate by a strain of Pseudomonas fluorescens isolated from a forest soil. Biology and Fertility of Soils. 28(1): 87-94.

Frassinetti, S., Bronzetti, G.L., Caltavuturo, L., Cini, M., Della Croce, C. 2006. The role of zinc in life: a review. Journal of environmental pathology, toxicology and oncology. 25(3): 597-610.

Gadd, G.M. 1999. Fungal production of citric and oxalic acid: importance in metal speciation, physiology and 
biogeochemical processes. Adv. Microb. Physiol. 41: 47-92.

Ghosh, P.K., Hazra, K.K., Kumar, N, Nadarajan, N, Venkatesh M.S. 2014. Resource Conservation Technology in Pulses. Scientific Publishers. Chapter 19, 'Zinc in crops and human health an overview'. pp. 213-223.

Jones, D.L., Darrah, P.R. 1994. Role of root derived organic acids in the mobilization of nutrients from the rhizosphere. Plant and soil. 166(2): 247-257.

Sayer, J.A. Raggett, S.L., Gadd, G.M. 1995. Solubilization of insoluble metal compounds by soil fungi: development of a screening method for solubilizing ability and metal tolerance. Mycol. Res. 99: 987-993.

Sillanpaa, M. 1990. Micronutrients Assessment at the Country Level, An international Study FAO Soils Bulletin
63, Food and Agriculture Organization of the United Nations.

Tahir, M., Shakeel, S.N. 2013. Buffer optimization for cyonodondactylon proteome. Journal of Proteomics and Bioinformatics. 6: 10-14.

Tiwari, K.N. Dwivedi, B.S. 1994. Available zinc status of soils and delineation of the areas of zinc deficiency in Uttar Pradesh. Fert. News. 39: 31-39.

Uroz, S., Calvaruso, C., Turpault, M. P., FreyKlett, P. 2009. Mineral weathering by bacteria: ecology, actors and mechanisms. Trends in microbiology. 17(8): 378-387.

Welch, S.A., Taunton, A.E., Banfield, J.F. 2002. Effect of microorganisms and microbial metabolites on apatite dissolution. Geomicrobiology Journal. 19(3): 343-367.

\section{How to cite this article:}

Vidyashree, D.N., R. Muthuraju, P. Panneerselvam and Debasis Mitra. 2018. Organic Acids Production by Zinc Solubilizing Bacterial Isolates. Int.J.Curr.Microbiol.App.Sci. 7(10): 626633. doi: https://doi.org/10.20546/ijcmas.2018.710.070 